\title{
Article \\ Comparison of New Kairomone-Based Lures for Cydia pomonella (Lepidoptera: Tortricidae) in Italy and USA
}

\author{
Michele Preti ${ }^{1}\left(\mathbb{D}\right.$, Alan L. Knight ${ }^{2}$, Riccardo Favaro ${ }^{1}$, Esteban Basoalto ${ }^{3} \mathbb{C}$, Marco Tasin ${ }^{4}\left(\mathbb{D}\right.$ and Sergio Angeli ${ }^{1, *} * \mathbb{C}$ \\ 1 Faculty of Science and Technology, Free University of Bozen-Bolzano, Piazza Università 5, 39100 Bolzano, \\ Italy; michele.preti@natec.unibz.it (M.P.); riccardo.favaro@unibz.it (R.F.) \\ 2 Instar Biologicals, Yakima, WA 98908, USA; uncfencer76@hotmail.com \\ 3 Facultad de Ciencias Agrarias, Instituto de Producción y Sanidad Vegetal, Universidad Austral de Chile, \\ Valdivia 5110566, Chile; esteban.basoalto@uach.cl \\ 4 Department of Chemical Sciences, University of Padua, Via Marzolo 1, 35121 Padua, Italy; \\ marco.tasin@unipd.it \\ * Correspondence: sergio.angeli@unibz.it
}

check for

updates

Citation: Preti, M.; Knight, A.L.; Favaro, R.; Basoalto, E.; Tasin, M.; Angeli, S. Comparison of New Kairomone-Based Lures for Cydia pomonella (Lepidoptera: Tortricidae) in Italy and USA. Insects 2021, 12, 72. https: / / doi.org/10.3390/

insects12010072

Received: 7 December 2020

Accepted: 12 January 2021

Published: 15 January 2021

Publisher's Note: MDPI stays neutral with regard to jurisdictional clai$\mathrm{ms}$ in published maps and institutional affiliations.

Copyright: $(\odot 2021$ by the authors. Licensee MDPI, Basel, Switzerland. This article is an open access article distributed under the terms and conditions of the Creative Commons Attribution (CC BY) license (https:// creativecommons.org/licenses/by/ $4.0 /)$.
Simple Summary: Adult codling moth (Cydia pomonella L.) monitoring with lure-baited traps is a prerequisite to effectively manage this key pest in apple and pear crops without over-spraying insecticides. We evaluated new multi-component lures comprised of blends of sex pheromone and volatile organic compounds (pear ester, dimethyl nonatriene and linalool oxide) loaded into different substrates (septa and PVC lures). Acetic acid in a second membrane lure was used as a co-lure with all blends. Lure comparisons were performed during the period 2019/2020 in Italy and Washington State (USA) in orchards treated with or without sex pheromone dispensers for mating disruption. The highest total moth counts occurred with the sex pheromone/pear ester PVC lure in both countries. The new multi-component PVC lure without sex pheromone captured the greatest number of female moths only in the USA. This geographical disparity may limit the effectiveness of using a 'female removal' strategy to manage this pest without insecticides across major production areas.

Abstract: Studies were conducted during the period 2019/2020 to evaluate the effectiveness of four lures for codling moth (Cydia pomonella L.) in pome fruits in Italy and the USA. Multi-component blends of sex pheromone ((E,E)-8,10-dodecadien-1-ol, $\mathrm{PH})$, pear ester ((E,Z)-2,4-ethyl decadienoate, $\mathrm{PE}),(E)-4,8$-dimethyl-1,3,7-nonatriene (DMNT), and pyranoid linalool oxide (6-ethenyl-2,2,6-trimethyloxan-3-ol, LOX) were loaded in either a halobutyl elastomer septum or a PVC matrix and always used in combination with acetic acid (AA) loaded in a closed membrane co-lure. Total moth capture was significantly greater with the PVC than the septum lure loaded with $\mathrm{PH} / \mathrm{PE}+\mathrm{AA}$ in both countries. Female capture in the USA study was significantly greater for 8 weeks in traps baited with the PE/DMNT/LOX blend + AA co-lure than with other lures and adding PH to this blend in a PVC lure significantly reduced female capture. In contrast, female capture in Italy did not differ among lures and counts were similar in both apple and pear crops treated with or without mating disruption. These results suggest that the effectiveness of 'female removal' strategies to manage codling moth may be geographically limited and further comparisons are needed in other production regions and in walnut.

Keywords: codling moth; sex pheromone; pear ester; acetic acid; dimethyl nonatriene; pyranoid linalool oxide; monitoring

\section{Introduction}

Codling moth, Cydia pomonella L. (Lepidoptera: Tortricidae), is a key world-wide pest of apple, Malus domestica L., pear, Pyrus spp., quince, Cydonia oblonga Mill., and walnut, Juglans regia L. [1,2]. The chemical ecology of the codling moth has been well investigated with several applications adopted by growers on a global scale for both 
monitoring and direct management [3-5]. The most important application has been the use of the female sex pheromone, $(E, E)-8,10$-dodecadien-1-ol $(\mathrm{PH})$, in lures to monitor male moth population dynamics [6,7], and within various dispensers, aerosols, and sprayable formulations for mating disruption (MD) [8-10]. Monitoring codling moth with PH lures within MD-treated orchards is challenging because male sexual behaviors are affected and moth captures in traps can be imprecise and variable [11,12]. The improved monitoring of codling moth in MD-treated orchards has been achieved with the use of pear ester, $(E, Z)-2,4-e t h y l$ decadienoate (PE), in combination with PH [13]. The use of additive or synergistic compounds, such as acetic acid (AA) [14] and (E)-4,8-dimethyl-1,3,7-nonatriene (DMNT) [15], with PE or PH/PE has increased the capture of codling moth and allowed female population densities to be tracked [16-19]. Recently, Knight et al. [20] reported that the addition of pyranoid linalool oxide, 6-ethenyl-2,2,6-trimethyloxan-3-ol (LOX), to the blend of PE + DMNT + AA significantly outperformed other non-pheromone and pheromone blends in untreated and MD-treated orchards [21]. The addition of $\mathrm{PH}$ to the $\mathrm{PE}+\mathrm{DMNT}+\mathrm{LOX}+\mathrm{AA}$ blend significantly increased total moth captures in MD-treated orchards. Both blends with or without $\mathrm{PH}$ were highly attractive to female codling moth, i.e., females comprised $>60 \%$ of the total captures $[20,21]$. The nearly 4 -fold increase in female captures compared to other lures [22] can promote the further development and greater adoption of 'female removal' as a viable management practice for codling moth [23]. To date, the effectiveness of these new multi-component blends has not been reported outside the USA or in host crops other than apple.

Previous field studies with PE-based lures found that their relative effectiveness in trapping both sexes of the codling moth was variable, and a number of significant factors were identified, including seasonality, trap height and color [24-29]. Of particular concern were reports of low female captures in PE-baited traps in some geographical regions [30-41]. Gray halobutyl elastomer septa were used as the matrix for $\mathrm{PH}$ and PE lures to provide extended effectiveness compared to red rubber septa [11,18,19,25,42]. A new black PVC proprietary matrix developed for long-lasting mating disruption dispensers has also been developed for a range of insect lures [43].

Here, we report the first study of the PVC matrix used for codling moth lures loaded with PH, PE, DMNT, and LOX, and used in combination with an AA co-lure. Studies were conducted in both apple and pear orchards treated with or without MD in Italy and in an untreated apple orchard in the USA during the period 2019/2020.

\section{Materials and Methods}

\subsection{Trapping Material and Lures}

Standard orange delta-shaped traps with sticky liners were used in all studies (Pherocon ${ }^{\circledR}$ VI, Trécé Inc., Adair, OK, USA). Two commercial lures were used in our studies, a grey halobutyl elastomer septum loaded with $3.5 \mathrm{mg}$ PH and $3.9 \mathrm{mg}$ PE (Pherocon ${ }^{\circledR} \mathrm{CM}-\mathrm{DA}$ Combo), and a white plastic closed membrane lure loaded with $720 \mathrm{mg}$ of AA (Pherocon ${ }^{\circledR}$ AA). Three new black PVC lures were also tested. The first PVC lure was loaded by Trécé Inc. with the same rates of compounds (PH/PE) as the septum lure (Pherocon ${ }^{\circledR} \mathrm{CM}$-DA Combo-P). Two experimental PVC lures were either loaded by Trécé Inc. with $3.9 \mathrm{mg}$ PE, $10 \mathrm{mg}$ of DMNT and $10 \mathrm{mg}$ LOX or these same three compounds plus $3.5 \mathrm{mg} \mathrm{PH}$.

\subsection{Lure Comparison Field Trials}

Lure comparisons were conducted during 2019 in one apple orchard not treated with MD in Washington State, USA, from 4 May to 22 July. The objective of this study was to determine the longevity of the lures over 4,8 , and 12 weeks of field exposure to reflect typical replacement schedules used with various alternative lures. In this lure longevity study, the lures were not replaced over the whole monitoring period (79 days) and codling moth captures were summarized on a monthly basis (ca. every four weeks) to assess the lures' performance over different time periods. Studies were also conducted in four apple and three pear plots in the Emilia-Romagna region, Italy, during the period 2019/2020, 
to evaluate lures in both crops and in orchards with or without MD (thirteen trials). In Italy, pome fruit orchards were either unsprayed (one apple plot and two pear plots) or managed according to the organic farming practices plus MD (three apple plots and one pear plot). Isomate ${ }^{\circledR}-\mathrm{C}$ TT (Shin-Etsu Chemical Co. Ltd., Chiyoda District, Japan) at 500 dispensers ha ${ }^{-1}$ (313 mg PH per dispenser) was applied in MD-treated apple plots, while the pear plot was treated with Cidetrak ${ }^{\circledR}$ Meso (Trécé Inc.) at 80 dispensers ha $^{-1}$ (1100 mg PH per dispenser). The purpose of the lures' evaluation study realized in Italy was to gain information about the lures' performance outside the USA and in different operative conditions. Trial duration varied from 3 to 12 weeks, covering the three codling moth flight periods (see Table S1 in Supplementary Material for details).

Experimental protocols were mostly standardized across the studies. Four blends were compared in every field trial: (1) the PH/PE blend loaded in a septum lure + AA membrane co-lure; (2) the PH/PE blend loaded in a PVC lure + AA membrane co-lure; (3) PE/DMNT/LOX blend loaded in a PVC lure + AA membrane co-lure; and (4) $\mathrm{PH} / \mathrm{PE} / \mathrm{DMNT} / \mathrm{LOX}$ blend loaded in a PVC lure + AA membrane co-lure. All lures were placed directly on the center area of the sticky liner placed inside the bottom of the trap. Traps with no lures were included as an untreated blank in each trial. Traps were placed within each orchard plot with a completely randomized experimental design and were spaced at least $25 \mathrm{~m}$ apart and from the orchard's perimeter. Each trap was attached to a bamboo pole to facilitate their placement at a height of $2.5-3.0 \mathrm{~m}$ in the canopy. Traps were checked, captures were counted and sexed, and liners were replaced weekly. Traps were not rotated in position during each trial. The number of replicates varied across studies: 8 traps per each of the 5 treatments in the USA lure longevity trial and 5 traps per each of the 5 treatments in each of the 13 Italian lure comparison trials.

\subsection{Statistical Analyses}

Statistical analyses of moth counts (females and total) were performed with R software version 4.0.3 (R Core Team 2020) [44], including the packages lme4 [45] and multcomp [46]. Figures were created using the package ggplot2 [47]. For the USA data, the effect of lure type on the codling moth captures was analyzed by using linear models $(\mathrm{lm})$, after data transformation with a square root $(x)$ to fit a normal distribution. The Italian data were analyzed by using generalized linear models ( $\mathrm{glm}$ ) or generalized linear mixed-effects models (glmer) with Poisson distribution, thus accounting for the variability within each trial. The models were tested for overdispersion (AER package). A negative binomial distribution (glm.nb function from the MASS package) was used in case of overdispersed models. Akaike's information criteria (AIC) and residuals were used to select the fitted models. Data from traps without lures were always excluded from the statistical analysis because these traps failed to capture moths during any trial. The Italian data were analyzed both together and separately for each crop and the use of MD. For the comprehensive analyses, a glmer with a Poisson distribution tested the effects of several factors on moth captures. Codling moth flight, trial duration, MD occurrence, grower management program (either unsprayed or organic), crop (either apple or pear) and year were considered as predictors together with the lure type, while the trial number was set as a random effect. The significance of the random effect was tested against a dummy model without a random effect. A multiple comparison post hoc test was performed on the fitted models (glht function from multcomp package) for both USA and Italian data and Tukey's test $(p<0.05)$ was adopted to discriminate differences.

\section{Results}

\subsection{Lures Longevity Study (USA)}

Traps captured large numbers of codling moths during the lure longevity study performed in the USA in 2019 (Table 1 and Figure 1). All three PVC lures captured significantly more moths than the PH/PE septum in the first two time periods. Interestingly, the PH/PE PVC lure captured significantly more males (between 3.3-fold and 9.3-fold) 
than the PH/PE septum lure during all the experiment. The two PVC lures with DMNT and LOX captured significantly more females than either PH/PE lures in the first two time periods. The addition of $\mathrm{PH}$ in the multi-component PVC lure significantly reduced the capture of females in both time periods. The relative performances of the lures changed in the third period. After 8 weeks of field exposure, the PH/PE PVC lure still captured significantly more total moths than the other three lures, but the multi-component PVC lure without PH only captured significantly more females than the $\mathrm{PH} / \mathrm{PE}$ septa lure. Over the entire 79 days of the experiment, the three PVC lures captured significantly more moths than the septum lure, the two PVC lures with DMNT and LOX captured significantly more females than the two PH/PE lures, and the addition of PH in the multi-component PVC lure reduced female captures (Table 1). The multi-component PVC lure without $\mathrm{PH}$ provided the highest female counts, with a final female proportion (mean $\pm \mathrm{SEM}$ ) of $0.56 \pm 0.02$, significantly greater than the female proportion of $0.35 \pm 0.02$ provided by the same blend plus $\mathrm{PH}(\mathrm{df}=3,28 ; \mathrm{F}=30.33 ; p<0.001)$.

Table 1. Mean ( \pm SEM) cumulative captures of codling moths in traps baited with four different combinations of $(E, E)$ 8,10-dodecadien-1-ol (sex pheromone, $\mathrm{PH}$ ), (E,Z)-2,4-ethyl decadienoate (pear ester, PE), (E)-4,8-dimethyl-1,3,7-nonatriene (DMNT), and linalool oxide (LOX) loaded into either an elastomer septum or a PVC matrix, and used in combination with a closed membrane lure loaded with acetic acid (AA), ( $=8$ ) over three consecutive time periods from 4 May to 22 July 2019 , USA.

\begin{tabular}{|c|c|c|c|c|}
\hline \multirow{2}{*}{$\begin{array}{c}\text { Start-End of Trapping } \\
\text { Period (d) }\end{array}$} & \multirow{2}{*}{ Lure Loading and Matrix ${ }^{a}$} & \multicolumn{3}{|c|}{ Mean $( \pm$ SEM) Moth Capture per Trap } \\
\hline & & Total & Females & Males \\
\hline \multirow{5}{*}{$0-31$} & $\mathrm{PH} / \mathrm{PE}$ (septum) + AA & $72.9 \pm 6.3 \mathrm{a}$ & $31.4 \pm 3.5 \mathrm{a}$ & $41.5 \pm 3.6 \mathrm{a}$ \\
\hline & $\mathrm{PH} / \mathrm{PE}(\mathrm{PVC})+\mathrm{AA}$ & $177.4 \pm 14.7 \mathrm{~b}$ & $40.3 \pm 5.1 \mathrm{a}$ & $137.1 \pm 15.7 \mathrm{~b}$ \\
\hline & $\mathrm{PE} / \mathrm{DMNT} / \mathrm{LOX}(\mathrm{PVC})+\mathrm{AA}$ & $204.4 \pm 16.4 \mathrm{~b}$ & $107.6 \pm 7.8 \mathrm{c}$ & $96.8 \pm 9.9 \mathrm{~b}$ \\
\hline & $\mathrm{PH} / \mathrm{PE} / \mathrm{DMNT} / \mathrm{LOX}(\mathrm{PVC})+\mathrm{AA}$ & $176.8 \pm 11.6 \mathrm{~b}$ & $66.0 \pm 3.7 \mathrm{~b}$ & $110.8 \pm 9.9 \mathrm{~b}$ \\
\hline & ANOVA: $\mathrm{df}=3,28$ & $F=35.95, p<0.001$ & $F=33.92, p<0.001$ & $F=26.61, p<0.001$ \\
\hline \multirow{5}{*}{$32-59$} & $\mathrm{PH} / \mathrm{PE}$ (septum) + AA & $9.2 \pm 1.5 \mathrm{a}$ & $3.3 \pm 0.8 \mathrm{a}$ & $5.9 \pm 1.2 \mathrm{a}$ \\
\hline & $\mathrm{PH} / \mathrm{PE}(\mathrm{PVC})+\mathrm{AA}$ & $58.8 \pm 7.1 c$ & $3.6 \pm 0.8 \mathrm{a}$ & $55.1 \pm 6.9 c$ \\
\hline & $\mathrm{PE} / \mathrm{DMNT} / \mathrm{LOX}(\mathrm{PVC})+\mathrm{AA}$ & $27.8 \pm 3.1 \mathrm{~b}$ & $20.4 \pm 2.7 c$ & $7.4 \pm 0.8 \mathrm{a}$ \\
\hline & $\mathrm{PH} / \mathrm{PE} / \mathrm{DMNT} / \mathrm{LOX}(\mathrm{PVC})+\mathrm{AA}$ & $36.9 \pm 5.2 \mathrm{bc}$ & $8.9 \pm 0.7 \mathrm{~b}$ & $28.0 \pm 5.3 \mathrm{~b}$ \\
\hline & ANOVA: $\mathrm{df}=3,28$ & $F=41.01, p<0.001$ & $F=26.12, p<0.001$ & $F=54.74, p<0.001$ \\
\hline \multirow{5}{*}{$60-79$} & $\mathrm{PH} / \mathrm{PE}$ (septum) + AA & $15.0 \pm 3.4 \mathrm{a}$ & $5.5 \pm 2.0 \mathrm{a}$ & $9.5 \pm 3.2 \mathrm{a}$ \\
\hline & $\mathrm{PH} / \mathrm{PE}(\mathrm{PVC})+\mathrm{AA}$ & $51.5 \pm 5.2 \mathrm{c}$ & $9.1 \pm 2.1 \mathrm{ab}$ & $42.5 \pm 5.1 \mathrm{c}$ \\
\hline & PE/DMNT/LOX (PVC) + AA & $17.1 \pm 1.9 \mathrm{ab}$ & $12.6 \pm 1.6 b$ & $4.4 \pm 0.7 \mathrm{a}$ \\
\hline & $\mathrm{PH} / \mathrm{PE} / \mathrm{DMNT} / \mathrm{LOX}(\mathrm{PVC})+\mathrm{AA}$ & $25.5 \pm 3.5 \mathrm{~b}$ & $6.5 \pm 1.2 \mathrm{ab}$ & $18.8 \pm 3.0 \mathrm{~b}$ \\
\hline & ANOVA: $\mathrm{df}=3,28$ & $F=14.75, p<0.001$ & $F=3.87, p=0.020$ & $F=23.44, p<0.001$ \\
\hline \multirow{5}{*}{$0-79$} & $\mathrm{PH} / \mathrm{PE}$ (septum) + AA & $94.6 \pm 9.5 \mathrm{a}$ & $39.1 \pm 4.4 \mathrm{a}$ & $55.5 \pm 7.1 \mathrm{a}$ \\
\hline & $\mathrm{PH} / \mathrm{PE}(\mathrm{PVC})+\mathrm{AA}$ & $281.0 \pm 19.9 b$ & $52.0 \pm 5.2 \mathrm{a}$ & $229.1 \pm 22.6 c$ \\
\hline & PE/DMNT/LOX (PVC) + AA & $244.3 \pm 17.8 b$ & $136.6 \pm 9.2 c$ & $107.5 \pm 9.9 b$ \\
\hline & $\mathrm{PH} / \mathrm{PE} / \mathrm{DMNT} / \mathrm{LOX}(\mathrm{PVC})+\mathrm{AA}$ & $233.6 \pm 16.3 \mathrm{~b}$ & $80.1 \pm 4.8 \mathrm{~b}$ & $153.3 \pm 14.4 \mathrm{bc}$ \\
\hline & ANOVA: $\mathrm{df}=3,28$ & $F=42.40, p<0.001$ & $F=39.15, p<0.001$ & $F=34.60, p<0.001$ \\
\hline
\end{tabular}

Column means within each period followed by different letters are significantly different, $p<0.05$ (Tukey's test). ${ }^{\text {a }}$ The acetic acid loaded in a membrane co-lure was placed close to the other lure in all traps. 

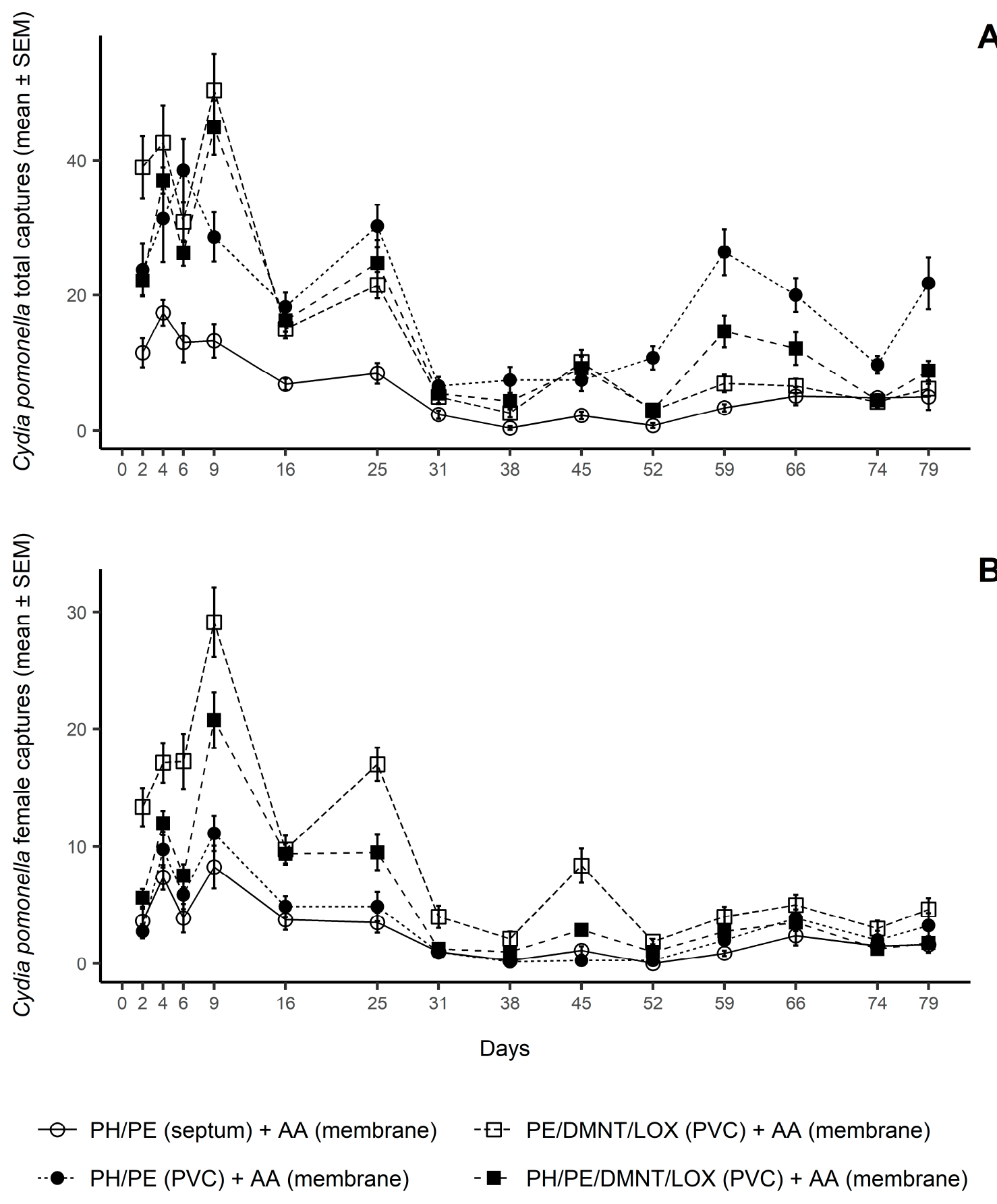

Figure 1. Mean $( \pm \mathrm{SEM})$ codling moth (Cydia pomonella L.) captures in the weekly trap checks recorded in the USA from 4 May to 22 July 2019. (A) = total captures; (B) = female captures. This lure longevity study tested four blend combinations of $(E, E)-8,10$-dodecadien-1-ol (sex pheromone, $\mathrm{PH}),(E, Z)$-2,4-ethyl decadienoate (pear ester, $\mathrm{PE}$ ), acetic acid (AA), (E)-4,8-dimethyl-1,3,7-nonatriene (DMNT), and linalool oxide pyranoid (LOX), over a 12-week monitoring period $(\mathrm{N}=8)$.

\subsection{Lures Evaluation in Different Field Conditions (Italy)}

Moth counts in the Italian unsprayed apple orchard were at least 2-fold higher than the ones recorded in the apple orchards treated with MD, while moth counts in the pear orchard treated with MD doubled the counts recorded in the unsprayed pear orchards (Table 2). 
Table 2. Cumulative mean $( \pm \mathrm{SEM})$ capture of codling moths in traps baited with different combinations of $(E, E)-8,10$ dodecadien-1-ol (sex pheromone, PH), (E,Z)-2,4-ethyl decadienoate (pear ester, PE), (E)-4,8-dimethyl-1,3,7-nonatriene (DMNT), linalool oxide (LOX) loaded into either an elastomer septum or a PVC matrix, and used in combination with a closed membrane lure loaded with acetic acid (AA), $(\mathrm{N}=5)$. Thirteen lure comparison trials were conducted in apple and pear orchards either unsprayed or organically managed with mating disruption (MD) in Italy during the period 2019/2020.

\begin{tabular}{|c|c|c|c|c|c|}
\hline \multirow{2}{*}{$\begin{array}{c}\text { Crop } \\
\text { (Number of } \\
\text { Trials) }\end{array}$} & \multirow{2}{*}{$\begin{array}{c}\text { Grower } \\
\text { Management }\end{array}$} & \multirow{2}{*}{ Lure Content and Matrix ${ }^{a}$} & \multicolumn{3}{|c|}{ Mean ( \pm SEM) Moth Capture per Trap } \\
\hline & & & Total & Females & Males \\
\hline Apple (1) & Unsprayed, no MD & $\begin{array}{c}\text { PH/PE (septum) + AA } \\
\text { PH/PE (PVC) + AA } \\
\text { PE/DMNT/LOX (PVC) + AA } \\
\text { PH/PE/DMNT/LOX (PVC) + AA }\end{array}$ & $\begin{array}{c}15.4 \pm 5.4 \mathrm{a} \\
38.4 \pm 6.6 \mathrm{~b} \\
12.0 \pm 2.4 \mathrm{a} \\
14.0 \pm 7.0 \mathrm{a} \\
\text { Negative Binomial } \\
\mathrm{X}^{2}=13.83, p=0.003\end{array}$ & $\begin{array}{c}3.0 \pm 1.1 \mathrm{a} \\
9.0 \pm 1.0 \mathrm{~b} \\
8.2 \pm 1.8 \mathrm{~b} \\
6.6 \pm 3.1 \mathrm{ab} \\
\text { Poisson } \\
\mathrm{X}^{2}=18.03, p<0.001\end{array}$ & $\begin{array}{c}12.4 \pm 4.6 \mathrm{ab} \\
29.4 \pm 6.1 \mathrm{~b} \\
3.8 \pm 0.8 \mathrm{a} \\
7.4 \pm 4.0 \mathrm{a} \\
\text { Negative Binomial } \\
\mathrm{X}^{2}=23.79, p<0.001\end{array}$ \\
\hline Apple (6) & Organic, MD & $\begin{array}{c}\text { PH/PE (septum) + AA } \\
\text { PH/PE (PVC) + AA } \\
\text { PE/DMNT/LOX (PVC) + AA } \\
\text { PH/PE/DMNT/LOX (PVC) + AA }\end{array}$ & $\begin{array}{c}6.4 \pm 1.3 \\
5.9 \pm 1.4 \\
6.0 \pm 1.1 \\
6.1 \pm 1.3 \\
\text { Negative Binomial } \\
X^{2}=2.61, p=0.455\end{array}$ & $\begin{array}{c}1.6 \pm 0.5 \\
0.5 \pm 0.2 \\
1.9 \pm 0.4 \\
2.1 \pm 0.5 \\
\text { Negative Binomial } \\
\mathrm{X}^{2}=6.69, p=0.083\end{array}$ & $\begin{array}{c}4.9 \pm 1.0 \\
5.4 \pm 1.4 \\
4.0 \pm 0.8 \\
4.1 \pm 1.0 \\
\text { Negative Binomial } \\
X^{2}=7.76, p=0.051\end{array}$ \\
\hline Pear (4) & Unsprayed, no MD & $\begin{array}{c}\mathrm{PH} / \mathrm{PE}(\text { septum })+\mathrm{AA} \\
\mathrm{PH} / \mathrm{PE}(\mathrm{PVC})+\mathrm{AA} \\
\mathrm{PE} / \mathrm{DMNT} / \mathrm{LOX}(\mathrm{PVC})+\mathrm{AA} \\
\mathrm{PH} / \mathrm{PE} / \mathrm{DMNT} / \mathrm{LOX}(\mathrm{PVC})+\mathrm{AA}\end{array}$ & $\begin{array}{c}9.9 \pm 2.1 \mathrm{~b} \\
11.5 \pm 4.3 \mathrm{~b} \\
7.6 \pm 1.7 \mathrm{ab} \\
4.2 \pm 1.1 \mathrm{a} \\
\text { Negative Binomial } \\
\mathrm{X}^{2}=15.75, p=0.001\end{array}$ & $\begin{array}{c}1.9 \pm 0.5 \\
2.5 \pm 1.2 \\
1.9 \pm 0.5 \\
1.3 \pm 0.4 \\
\text { Negative Binomial } \\
\mathrm{X}^{2}=2.32, p=0.509\end{array}$ & $\begin{array}{c}7.9 \pm 1.8 \mathrm{~b} \\
9.0 \pm 3.4 \mathrm{~b} \\
5.7 \pm 1.6 \mathrm{ab} \\
2.9 \pm 0.8 \mathrm{a} \\
\text { Negative Binomial } \\
\mathrm{X}^{2}=16.80, p<0.001\end{array}$ \\
\hline Pear (2) & Organic, MD & $\begin{array}{c}\mathrm{PH} / \mathrm{PE}(\text { septum })+\mathrm{AA} \\
\mathrm{PH} / \mathrm{PE}(\mathrm{PVC})+\mathrm{AA} \\
\mathrm{PE} / \mathrm{DMNT} / \mathrm{LOX}(\mathrm{PVC})+\mathrm{AA} \\
\mathrm{PH} / \mathrm{PE} / \mathrm{DMNT} / \mathrm{LOX}(\mathrm{PVC})+\mathrm{AA}\end{array}$ & $\begin{array}{c}23.9 \pm 5.8 \mathrm{bc} \\
28.1 \pm 3.7 \mathrm{c} \\
9.2 \pm 1.6 \mathrm{a} \\
11.4 \pm 2.5 \mathrm{ab} \\
\text { Negative Binomial } \\
\mathrm{X}^{2}=19.71, p<0.001\end{array}$ & $\begin{array}{c}2.6 \pm 0.4 \mathrm{ab} \\
1.2 \pm 0.4 \mathrm{a} \\
3.7 \pm 0.9 \mathrm{~b} \\
1.6 \pm 0.4 \mathrm{a} \\
\text { Poisson } \\
\mathrm{X}^{2}=15.14, p=0.002\end{array}$ & $\begin{array}{c}21.3 \pm 5.5 \mathrm{~b} \\
26.9 \pm 3.6 \mathrm{~b} \\
5.6 \pm 1.1 \mathrm{a} \\
9.7 \pm 2.2 \mathrm{a} \\
\text { Negative Binomial } \\
\mathrm{X}^{2}=31.79, p<0.001\end{array}$ \\
\hline $\begin{array}{l}\text { Apple and } \\
\text { pear (13) }\end{array}$ & $\begin{array}{l}\text { Comprehensive } \\
\text { analysis }\end{array}$ & $\begin{array}{c}\text { PH/PE (septum) + AA } \\
\text { PH/PE (PVC) + AA } \\
\text { PE/DMNT/LOX (PVC) + AA } \\
\text { PH/PE/DMNT/LOX (PVC) + AA }\end{array}$ & $\begin{array}{c}10.9 \pm 1.5 \mathrm{bc} \\
15.4 \pm 2.3 \mathrm{c} \\
7.5 \pm 0.8 \mathrm{ab} \\
7.0 \pm 1.0 \mathrm{a} \\
\text { Negative Binomial } \\
\mathrm{X}^{2}=26.71, p<0.001\end{array}$ & $\begin{array}{c}2.0 \pm 0.3 \\
2.0 \pm 0.5 \\
2.7 \pm 0.4 \\
2.1 \pm 0.4 \\
\text { Negative Binomial } \\
\mathrm{X}^{2}=4.87, p=0.182\end{array}$ & $\begin{array}{c}9.0 \pm 1.3 \mathrm{~b} \\
13.3 \pm 2.0 \mathrm{c} \\
4.8 \pm 0.6 \mathrm{a} \\
4.9 \pm 0.7 \mathrm{a} \\
\text { Negative Binomial } \\
\mathrm{X}^{2}=46.74, p<0.001\end{array}$ \\
\hline
\end{tabular}

Column means within each crop-management category followed by different letters are significantly different, $p<0.05$ (Tukey's test). $\mathrm{X}^{2}=$ chi-square value for the factor lure, $p=$ probability $p\left(\mathrm{X}^{2}\right)$ for differences among lures. ${ }^{\text {a }}$ The acetic acid loaded in a membrane co-lure was placed close to the other lure in all traps.

The PH/PE PVC lure captured significantly more total moths than other lures only in the apple trial without. The multi-component PVC lure with PH captured significantly fewer moths than the PH/PE lures in no-MD pear trial. The multi-component PVC lure captured significantly more females than the $\mathrm{PH} / \mathrm{PE}$ septum lure in the no-MD apple trial and both the PH/PE PVC and multi-component with PH added PVC lures in the pear-MD trials. The PH/PE PVC lure captured significantly more females than the septum lure in the apple no-MD trial.

Comprehensive data analysis of Italian trials $(\mathrm{df}=219)$ showed no significant effect of codling moth flight $(\mathrm{z}$ value $=0.014$ and $p=0.989 ; \mathrm{z}$ value $=0.853$ and $p=0.394$ for the second and third flight, respectively), trial duration ( $z$ value $=-1.719$ and $p=0.086$ ), MD occurrence $(z$ value $=-0.936$ and $p=0.349)$, year $(z$ value $=1.372$ and $p=0.170)$, and crop $(z$ value $=1.426$ and $p=0.154)$ on the total codling moth captures. The same result was obtained for female and male captures. In the comprehensive analysis, the PH/PE PVC lure captured significantly more total moths than either of the PVC lures including DMNT/LOX. This significant difference was due to the male captures, which used the $\mathrm{PH} / \mathrm{PE}$ PVC lure and were 1.5-fold higher than using the same $\mathrm{PH} / \mathrm{PE}$ blend in the septum lure, both in combination with an AA co-lure. On the contrary, female captures were similar for all lures (Table 2). The multi-component PVC lure without PH provided the highest female counts, with a female proportion (mean \pm SEM) of $0.38 \pm 0.04$, not different from the female proportion of $0.33 \pm 0.04$ provided by the same blend plus $\mathrm{PH}(\mathrm{df}=3,201$; $\mathrm{F}=10.42 ; p=0.997)$. 


\section{Discussion}

Studies conducted in Italy and the USA with the new multi-component PVC lures provided contrasting results between countries and with the earlier reports of blend activities [20,21]. The original discovery used separate lures for each of the five compounds compared with the new PVC lure in which three or four compounds were loaded together; and both studies used the same AA membrane co-lure. Here, we found that adding PH to the multi-component PVC lure significantly reduced female codling moth captures in apple in the USA; but a similar effect in Italy was only seen in pear treated with MD dispensers. Previously, no difference in male or female captures were found if $\mathrm{PE}$ and $\mathrm{PH}$ were loaded into separate lures or combined in one septum [12,31]. Unfortunately, several studies evaluating the PE-PH combination in other countries did not make this exact comparison $[33,36,38]$. Our data here suggest that loading $\mathrm{PH}$ with the three plant volatiles in the PVC lure would diminish the potential of using 'female removal' to suppress codling moth populations, unless $\mathrm{PH}$ is released from a separate lure. However, further studies comparing these blends with $\mathrm{PH}$ released either by the same lure matrix including the three other compounds or by a close lure should confirm this hypothesis.

Our current study found that the new PVC matrix outperformed the septum lure with a PH/PE loading plus the use of the AA co-lure in both countries. However, only in Italy did the four lures capture similar numbers of female codling moths. Following the development of PE as an attractant for codling moths, at least one study in Italy suggested that PE might not be so effective for female moths [48]. However, more extensive electrophysiological, oviposition, and trapping studies in Italy demonstrated that the female codling moth did respond to PE similarly to populations in the USA [30,35,49]. Our new results suggest that different geographical populations of codling moth may have responses to host plant or microbial volatiles as variable as moth species have shown with sex pheromones [50,51].

PE is a major volatile component from ripe pears, and an initial hypothesis was made that it would be less effective in pear orchards due to volatile masking [24]. However, a series of studies demonstrated that PE was an effective lure for codling moth in many cultivars of pear $[31,37,38,52,53]$. PE was only found to be less effective in pear in one study under a specific set of conditions: late in the season in 'Bartlett' pear orchards characterized by high moth counts in traps and the presence of fruit injury [53]. In Italy, both for total moth captures and the proportion of females captured we found no apparent difference in the performance of the new multi-component lures between apple and pear.

The emission rate and blend ratios likely change continuously over time with any multi-component lure [54]. The USA study showed that the four-component PVC lure appeared to have diminished attraction for codling moths after 6 weeks when compared with the standard PE-PH lure. Previous studies have shown that DMNT in a grey halobutyl septum was an effective attractant for only 3-4 weeks [18], likely due to a rapid loss in the residual content of field-aged lures, i.e., 50\% drop in 7 days [16]. However, both PE/PH and AA lures have been shown to be long lasting $[19,29]$. The emission rate of LOX from lures has not been reported. Eliminating DMNT from the four-component blend can reduce the lure's attractiveness 3-fold [20]. Thus, it appears that the four-component lure gradually loses its effectiveness as the contribution of DMNT in the blend is reduced. Further studies are needed to assess and confirm this hypothesis, evaluating the emission rates of the various components loaded into the PVC matrix over time.

The failure of the four- and five-component lures in Italy to provide superior performance to the standard $\mathrm{PH} / \mathrm{PE}+\mathrm{AA}$ lure suggests that additional host plant volatile blends in combination with AA should be investigated. Extensive work in the USA has identified several four-component blends with PE, DMNT, and AA plus one of several terpenes from apple, pear, and walnuts, i.e., $\beta$-myrcene, $\beta$-pinene, $\alpha$-farnesene and $\beta$-farnesene [55]. Similar studies should be conducted in Italy and other production areas to validate the effectiveness of these new blends prior to developing 'female removal' tactics. 


\section{Conclusions}

Reliable surveillance of codling moth flight provides useful information for the timely management of pest population and limit crop losses. However, only monitoring male moths requires a robust correlation with key life history events, i.e., female egg laying and larval eclosion [56]. Thus, monitoring female populations should be a more accurate approach to predict key events $[57,58]$. The recent availability of new kairomone-based blends such as the four-component lure with enhanced formulations (PVC dispensers instead of septa) will likely open new approaches to monitor and manage this important pest. However, inherent behavioral differences among geographical populations of codling moth will need to be considered in this development.

Supplementary Materials: The following are available online at https://www.mdpi.com/2075-445 0/12/1/72/s1, Table S1: Summary of 14 lure trials for codling moths (Cydia pomonella L.) conducted in unsprayed and organic apple and pear orchards treated with or without mating disruption (MD) in Washington State, USA, and in the Emilia-Romagna Region, Italy, during the period 2019/2020.

Author Contributions: Conceptualization and methodology, M.P. and A.L.K.; investigation, M.P., A.L.K., M.P. and E.B.; data curation and statistical analysis, M.P. and R.F.; writing-original draft preparation, M.P.; writing - review and editing, M.P., R.F., E.B., M.T., A.L.K. and S.A.; supervision, S.A. All authors have read and agreed to the published version of the manuscript.

Funding: This research received no external funding.

Institutional Review Board Statement: Not applicable.

Informed Consent Statement: Not applicable.

Data Availability Statement: Data available on request.

Acknowledgments: The authors thank Trécé Inc. for supplying the lures and trapping materials.

Conflicts of Interest: The authors declare no conflict of interest. The funders had no role in the design of the study; in the collection, analyses, or interpretation of data; in the writing of the manuscript, or in the decision to publish the results.

\section{References}

1. Barnes, M.M. Codling moth occurrence, host race formation and damage. In World Crop Pests. Vol. 5. Tortricid Pests: Their Biology, Natural Enemies and Control; van der Geest, L.P.S., Evenhuis, H.H., Eds.; Elsevier Science Publishers: Amsterdam, The Netherlands, 1991; pp. 313-328.

2. Knight, A.L.; Judd, G.J.; Gilligan, T.; Fuentes-Contreras, E.; Walker, W.B. Integrated management of tortricid pests of tree fruit. In Integrated Management of Diseases and Insect Pests of Tree Fruit; Xu, X., Fountain, M., Eds.; Burleigh Dodds Science Publishing: Cambridge, UK, 2019; ISBN 978178676256 6. [CrossRef]

3. Witzgall, P.; Stelinski, L.; Gut, L.; Thomson, D. Codling moth management and chemical ecology. Annu. Rev. Entomol. 2008, 53, 503-522. [CrossRef]

4. Witzgall, P.; Kirsch, P.; Cork, A. Sex pheromones and their impact on pest management. J. Chem. Ecol. 2010, 36, 80-100. [CrossRef] [PubMed]

5. Kadoić Balaško, M.; Bažok, R.; Mikac, K.M.; Lemic, D.; Pajač Živković, I. Pest management challenges and control practices in codling moth: A review. Insects 2020, 11, 38. [CrossRef] [PubMed]

6. Adams, C.G.; Schenker, J.H.; McGhee, P.S.; Gut, L.J.; Brunner, J.F.; Miller, J.R. Maximizing information yield from pheromonebaited monitoring traps: Estimating plume reach, trapping radius, and absolute density of Cydia pomonella (Lepidoptera: Tortricidae) in Michigan apple. J. Econ. Entomol. 2017, 110, 305-318. [CrossRef] [PubMed]

7. Adams, C.G.; Schenker, J.H.; Weston, P.; Gut, L.J.; Miller, J.R. Path meander of male codling moths (Cydia pomonella) foraging for sex pheromone plumes: Field validation of a novel method for quantifying path meander of random movers developed using computer simulations. Insects 2020, 11, 549. [CrossRef] [PubMed]

8. Cardé, R.T.; Minks, A.K. Control of moth pests by mating disruption: Successes and constraints. Annu. Rev. Entomol. 1995, 40, 559-585. [CrossRef]

9. Miller, J.R.; Gut, L.J. Mating disruption for the 21st century: Matching technology with mechanism. Environ. Entomol. 2015, 44, 427-453. [CrossRef]

10. Ioriatti, C.; Lucchi, A. Semiochemical strategies for tortricid moth control in apple orchards and vineyards in Italy. J. Chem. Ecol. 2016, 42, 571-583. [CrossRef] 
11. Knight, A.L.; Light, D.M. Developing action thresholds for codling moth (Lepidoptera: Tortricidae) with pear ester-and codlemonebaited traps in apple orchards treated with sex pheromone mating disruption. Can. Entomol. 2005, 137, 739-747. [CrossRef]

12. Knight, A.L.; Hilton, R.; Light, D.M. Monitoring codling moth (Lepidoptera: Tortricidae) in apple with blends of ethyl (E,Z)-2,4decadienoate and codlemone. Environ. Entomol. 2005, 34, 598-603. [CrossRef]

13. Knight, A.L.; Light, D.M.; Judd, G.J.; Witzgall, P. Pear ester-from discovery to delivery for improved codling moth management. In Roles of Natural Products for Biorational Pesticides in Agriculture; Beck, J.J., Rering, C.C., Duke, S.O., Eds.; American Chemical Society: Washington, DC, USA, 2018; pp. 83-113. [CrossRef]

14. Landolt, P.J.; Suckling, D.M.; Judd, G.J.R. Positive interaction of a feeding attractant and a host kairomone for trapping the codling moth, Cydia pomonella (L.). J. Chem. Ecol. 2007, 33, 2236-2244. [CrossRef] [PubMed]

15. Knight, A.L.; Light, D.M.; Trimble, R.M. Identifying (E)-4,8-dimethyl-1,3,7-nonatriene plus acetic acid as a new lure for male and female codling moth (Lepidoptera: Tortricidae). Environ. Entomol. 2011, 40, 420-430. [CrossRef]

16. Knight, A.L.; Hilton, R.; Basoalto, E.; Stelinski, L.L. Use of glacial acetic acid to enhance bisexual monitoring of tortricid pests with kairomone lures in pome fruits. Environ. Entomol. 2014, 43, 1628-1640. [CrossRef] [PubMed]

17. Barros-Parada, W.; Basoalto, E.; Fuentes-Contreras, E.; Cichon, L.; Knight, A.L. Acetic acid lure placement within traps affects moth catches of codling moth (Lepidoptera: Tortricidae). J. Appl. Entomol. 2016, 140, 786-795. [CrossRef]

18. Knight, A.L.; Light, D.M. Monitoring codling moth (Lepidoptera: Tortricidae) in sex pheromone-treated orchards with (E)-4,8dimethyl-1,3,7-nonatriene or pear ester in combination with codlemone and acetic acid. Environ. Entomol. 2012, 41, 407-414. [CrossRef]

19. Knight, A.L.; Light, D.; Chebny, V. Monitoring codling moth (Lepidoptera: Tortricidae) in orchards treated with pear ester and sex pheromone combo dispensers. J. Appl. Entomol. 2013, 137, 214-224. [CrossRef]

20. Knight, A.L.; Mujica, V.; Larsson Herrera, S.; Tasin, M. Addition of terpenoids to pear ester plus acetic acid increases catches of codling moth (Lepidoptera: Tortricidae). J. Appl. Entomol. 2019, 143, 813-821. [CrossRef]

21. Knight, A.L.; Mujica, V.; Larsson Herrera, S.; Tasin, M. Monitoring codling moth (Lepidoptera: Tortricidae) with a four-component volatile blend compared to a sex pheromone-based blend. J. Appl. Entomol. 2019, 143, 942-947. [CrossRef]

22. Landolt, P.J.; Ohler, B.; Lo, P.; Cha, D.; Davis, T.S.; Suckling, D.M.; Brunner, J. N-Butyl sulfide as an attractant and coattractant for male and female codling moth (Lepidoptera: Tortricidae). Environ. Entomol. 2014, 43, 291-297. [CrossRef]

23. Jaffe, B.D.; Guédot, C.; Landolt, P.J. Mass-trapping codling moth, Cydia pomonella (Lepidopteran: Torticidae), using a kairomone lure reduces fruit damage in commercial apple orchards. J. Econ. Entomol. 2018, 111, 1983-1986. [CrossRef]

24. Light, D.M.; Knight, A.L.; Henrick, C.A.; Rajapaska, D.; Lingren, B.; Dickens, J.C.; Reynolds, K.M.; Buttery, R.G.; Merrill, G.; Roitman, J.; et al. A pear derived kairomone with pheromonal potency that attracts male and female codling moth, Cydia pomonella (L.). Naturwissenschaften 2001, 88, 333-338. [CrossRef] [PubMed]

25. Knight, A.L.; Light, D.M. Seasonal flight patterns of codling moth (Lepidoptera: Tortricidae) monitored with pear ester and codlemone-baited traps in sex pheromone-treated apple orchards. Environ. Entomol. 2005, 34, 1028-1035. [CrossRef]

26. Knight, A.L.; Light, D.M. Factors affecting the differential capture of male and female codling moth (Lepidoptera: Tortricidae) in traps baited with ethyl (E,Z)-2,4-decadienoate. Environ. Entomol. 2005, 34, 1161-1169. [CrossRef]

27. Knight, A.L.; Fisher, J. Increased catch of codling moth (Lepidoptera: Tortricidae) in semiochemical-baited orange plastic delta-shaped traps. Environ. Entomol. 2006, 35, 1597-1602. [CrossRef]

28. Knight, A.L. Increased catch of female codling moth (Lepidoptera: Tortricidae) in kairomone-baited clear delta traps. Environ. Entomol. 2010, 39, 583-590. [CrossRef] [PubMed]

29. Knight, A. Improved monitoring of female codling moth (Lepidoptera: Tortricidae) with pear ester plus acetic acid in sex pheromone-treated orchards. Environ. Entomol. 2010, 39, 1283-1290. [CrossRef]

30. Ioriatti, C.; Molinari, F.; Pasqualini, E.; De Cristofaro, A.; Schmidt, S.; Espinha, I. The plant volatile attractant (E,Z)-2,4-ethyldecadienoate (DA2313) for codling moth monitoring. Bull. Zool. Agric. 2003, 35, 127-137.

31. Il'ichev, A.L. First Australian trials of ethyl $(2 E, 4 Z)-2,4$-decadienoate for monitoring of female and male codling moth Cydia pomonella L. (Lepidoptera: Tortricidae) in pome fruit orchards. Gen. Appl. Entomol. 2004, 33, 15-20.

32. Knight, A.L.; Light, D.M. Dose-response of codling moth (Lepidoptera: Tortricidae) to ethyl (E,Z)-2,4-decadienoate in apple orchards treated with sex pheromone dispensers. Environ. Entomol. 2005, 34, 604-609. [CrossRef]

33. Trimble, R.M.; El-Sayed, A.M. Potential of ethyl (2E,4Z)-2,4-decadienoate for monitoring activity of codling moth (Lepidoptera: Tortricidae) in eastern North American apple orchards. Can. Entomol. 2005, 137, 110-116. [CrossRef]

34. Kutinkova, H.; Subchev, M.; Light, D.; Lingren, B. Interactive effects of ethyl (2E,4Z)-2,4-decadienoate and sex pheromone lures to codling moth: Apple orchard investigations in Bulgaria. J. Plant Prot. Res. 2005, 45, 49-53.

35. Schmidt, S.; Anfora, G.; Ioriatti, C.; Germinara, G.S.; Rotundo, G.; De Cristofaro, A. Biological activity of ethyl (E, Z)-2,4decadienoate on different tortricid species: Electrophysiological responses and field tests. Environ. Entomol. 2007, 36, 1025-1031. [CrossRef]

36. Mitchell, V.J.; Manning, L.A.; Cole, L.; Suckling, D.M.; El-Sayed, A.M. Efficacy of the pear ester as a monitoring tool for codling moth Cydia pomonella (Lepidoptera: Tortricidae) in New Zealand apple orchards. Pest Manag. Sci. 2008, 64, 209-214. [CrossRef]

37. Il'ichev, A.L.; Van De Ven, R.; Williams, D.G.; Penfold, N. Monitoring codling moth 'Cydia pomonella' L. (Lepidoptera: Tortricidae) in Victorian pome fruit orchards with pear ester. Gen. Appl. Ent. 2009, 38, 57-64. 
38. Fernandez, D.E.; Cichon, L.; Garrido, S.; Ribes-Dasi, M.; Avilla, J. Comparison of lures loaded with codlemone and pear ester for capturing codling moths, Cydia pomonella, in apple and pear orchards using mating disruption. J. Insect Sci. 2010, 10, 139. [CrossRef] [PubMed]

39. Joshi, N.K.; Hull, L.A.; Rajotte, E.G.; Krawczyk, G.; Bohnenblust, E. Evaluating sex-pheromone-and kairomone-based lures for attracting codling moth adults in mating disruption versus conventionally managed apple orchards in Pennsylvania. Pest Manag. Sci. 2011, 67, 1332-1337. [CrossRef] [PubMed]

40. Hári, K.; Pénzes, B.; Jósvai, J.; Holb, I.; Szarukán, I.; Szólláth, I.; Vitányi, I.; Koczor, S.; Ladányi, M.; Tóth, M. Performance of traps baited with pear ester-based lures vs. pheromone baited ones for monitoring codling moth Cydia pomonella L. in Hungary. Acta Phytopathol. et Entomol. Hung. 2011, 46, 225-234. [CrossRef]

41. Tóth, M.; Jósvai, J.; Hári, K.; Pénzes, B.; Vuity, Z.; Holb, I.; Szarukán, I.; Kecskés, Z.; Dorgán-Zsuga, I.; Koczor, S.; et al. Pear ester based lures for the codling moth Cydia pomonella L.-A summary of research efforts in Hungary. Acta Phytopathol. Entomol. Hung. 2014, 49, 37-47. [CrossRef]

42. Knight, A.L. A comparison of gray halo-butyl elastomer and red rubber septa to monitor codling moth (Lepidoptera: Tortricidae) in sex pheromone-treated orchards. J. Entomol. Soc. Br. Columbia 2002, 99, 123-132.

43. Trécé Inc. 2020. Available online: https:/ / www.trece.com/ (accessed on 25 November 2020).

44. R Core Team 2020. R: A Language and Environment for Statistical Computing. R Foundation for Statistical Computing, Vienna, Austria. R version 4.0.3 (2020-10-10). Available online: https:/ / www.R-project.org/ (accessed on 17 November 2020).

45. Bates, D.; Mächler, M.; Bolker, B.; Walker, S. Fitting Linear Mixed-Effects Models Using lme4. J. Stat. Softw. 2015, 67, 1-48. [CrossRef]

46. Hothorn, T.; Bretz, F.; Westfall, P. Simultaneous Inference in General Parametric Models. Biom. J. 2008, 50, 346-363. [CrossRef] [PubMed]

47. Wickham, H. ggplot2: Elegant Graphics for Data Analysis; Springer: New York, NY, USA, 2016; ISBN 978-3-319-24277-4. Available online: https: / ggplot2.tidyverse.org (accessed on 17 November 2020).

48. Trematerra, P.; Sciarretta, A. Activity of the kairomone ethyl (E,Z)-2,4-decadienoate in the monitoring of Cydia pomonella (L.) during the second annual flight. Redia 2005, LXXXVIII, 57-62.

49. Pasqualini, E.; Schmidt, S.; Espiñha, I.; Civolani, S.; De Cristofaro, A.; Molinari, F.; Villa, M.; Ladurner, E.; Ioriatti, C. Effects of the kairomone ethyl (2E, 4Z)-2, 4-decadienoate (DA 2313) on the oviposition behaviour of Cydia pomonella: Preliminary investigations. Bull. Insect. 2005, 58, 119.

50. Löfstedt, C. Population variation and genetic control of pheromone communication systems in moths. Entomol. Exp. Appl. 1990, 54, 199-218. [CrossRef]

51. Dekker, T.; Kárpáti, Z. Coding and evolution of pheromone preference in moths. In Insect Sex Pheromone Research and Beyond. Entomology Monographs; Ishikawa, Y., Ed.; Springer: Singapore, 2020. [CrossRef]

52. Knight, A.L.; Light, D.M. Use of ethyl and propyl (E,Z)-2,4-decadienoates in codling moth management: Improved monitoring in Bartlett pear with high dose lures. J. Entomol. Soc. Br. Columbia 2004, 101, 45-52.

53. Knight, A.L.; VanBuskirk, P.; Hilton, R.; Zoller, B.; Light, D.M. Monitoring codling moth (Lepidoptera: Tortricidae) in four cultivars of pear. Acta Hort 2005, 594, 120-125.

54. Kuenen, L.P.S.; Siegel, J.P. Measure your septa release ratios: Pheromone release ratio variability affected by rubber septa and solvent. J. Chem. Ecol. 2015, 41, 303-310. [CrossRef]

55. Preti, M.; Knight, A.L.; Mujica, V.; Basoalto, E.; Herrera, S.L.; Tasin, M.; Angeli, S. Development of multi-component non-sex pheromone blends to monitor both sexes of Cydia pomonella (Lepidoptera: Tortricidae). J. Appl. Entomol. 2020, submitted.

56. Graf, B.; Höhn, H.; Höpli, H.U.; Kuske, S. Predicting the phenology of codling moth, Cydia pomonella, for sustainable pest management in Swiss apple orchards. Entomol. Exp. Appl. 2018, 166, 618-627. [CrossRef]

57. Pasquali, S.; Soresina, C.; Gilioli, G. The effects of fecundity, mortality and distribution of the initial condition in phenological models. Ecol. Model. 2019, 402, 45-58. [CrossRef]

58. Barros-Parada, W.; Knight, A.L.; Fuentes-Contreras, E. Modeling codling moth (Lepidoptera: Tortricidae) phenology and predicting egg hatch in apple orchards of the Maule Region, Chile. Chil. J. Agric. Res. 2015, 75, 57-62. [CrossRef] 